\title{
Occurrence of Escherichia coli in cloacal samples of broiler chicken from Kollam and Kottayam districts ${ }^{\#}$
}

\author{
S. Afsal ${ }^{\star 1}$, C. Latha ${ }^{2}$, C. Sethulekshmi ${ }^{3}$, M. Binsy ${ }^{3}$, C. J. Beena ${ }^{4}$ and V.L. Gleeja ${ }^{5}$ \\ Department of Veterinary Public Health College of \\ Veterinary and Animal Sciences, Mannuthy, Thrissur-680651, \\ Kerala Veterinary and Animal Sciences University, Kerala, India.
}

Citation: Afsal, S., Latha, C., Sethulekshmi, C., Binsy, M., Beena, C. J. and Gleeja, V.L. 2021. Occurrence of Escherichia coli in cloacal samples of broiler chicken from Kollam and Kottayam districts. J. Vet. Anim. Sci. 52(4): 371-376

DOI: https://doi.org/10.51966/jvas.2021.52.4.371-376

Received: 27.02.2021

Accepted:15.03.2021

Published: 15.12.2021

\begin{abstract}
Foodborne pathogens like E. coli are considered as the major causes of foodborne illness in humans worldwide. The present study was undertaken to determine the occurrence of E. coli in cloacal samples of broiler chicken from Kollam and Kottayam districts. The occurrence of E. coli in cloacal samples from broiler chicken was 76.5 per cent from Kollam and 79 per cent from Kottayam through culture techniques. Out of the total 400 cloacal swab samples collected from broiler chicken, 77.8 per cent were positive for E. coli. The samples which were subjected to conventional culture techniques were further analysed for PCR confirmation. The study revealed that, 56.5 and 67 per cent samples were positive for E. coli from Kollam and Kottayam, respectively. An overall occurrence of 61.8 per cent out of 400 samples were confirmed for E. coli by PCR. One Health approach can be used as a suitable tool to combat the foodborne zoonotic diseases, since it is an integrated, multidisciplinary, holistic approach. Proper implementation of biosecurity measures in farms is mandatory to control foodborne zoonotic diseases.
\end{abstract}

Keywords: E. coli, broiler chicken, one health

Running title: Occurrence of Escherichia coli in cloacal samples

Foodborne illnesses are usually infectious or toxic in nature caused by bacteria, viruses, parasites or chemical substances, entering the body through contaminated food or water. It is often caused by ingestion of eggs, raw or undercooked meat, fresh produce and dairy products

\#Part of MVSc thesis submitted to Kerala Veterinary and Animal Sciences University, Pookode, Wayanad, Kerala

1. MVSc Scholar and *Corresponding author. Email-afsalsudheer007@gmail.com

2. Professor and Head

3. Assistant Professor

4. Assistant Professor and Head, AICRP, KVASU

5. Assistant Professor, Department of Statistics

Copyright: (02021 Afsal et al. This is an open access article distributed under the terms of the Creative Commons Attribution 4.0 International License (http://creativecommons.org/licenses/by/4.0/), which permits unrestricted use, distribution, and reproduction in any medium, provided the original author and source are credited. 
contaminated by norovirus, Campylobacterspp., non-typhoidal Salmonella and pathogenic $E$. coli (WHO, 2015). Escherichia coli causes diarrheal diseases, which account for more than four per cent of the total daily global disease burden every day. It also leads to 1.8 million deaths every year, among which 90 per cent were children (Yulistiani and Praseptiangga, 2019). They are the most important foodborne pathogens of Enterobacteriaceae family, which causes foodborne illness transmitted mainly through poultry products. Hence, the present study was designed with an objective to find the occurrence of $E$. coli in cloacal samples of broiler chicken.

\section{Materials and methods}

The present study was undertaken to determine the occurrence of $E$. coli in cloacal samples of broiler chicken and molecular confirmation of the positive isolates. A total of 400 cloacal swab samples from broiler chicken were collected from different farms of Kollam and Kottayam districts of Kerala. From each district 200 samples were collected for a period of 12 months from October 2019 to November 2020.

After sampling, the cloacal swabs were aseptically placed in tubes containing peptone water. The samples were brought to the laboratory in a thermocool container within
$24 \mathrm{~h}$ for further isolation and identification by conventional culture techniques. The samples in peptone water were streaked on to MacConkey agar (MCA) incubated at $37^{\circ} \mathrm{C}$ for $24 \mathrm{~h}$. Followed by plating of lactose fermenting colonies onto EMB agar and incubated at $37^{\circ} \mathrm{C}$ for $24 \mathrm{~h}$. Colonies with typical characteristics of greenish metallic sheen with dark centre were selected for further confirmation by PCR. The boiling and snap chilling technique was used for the preparation of DNA template (Lee et al., 2009).

The molecular reagents and chemicals used in the study were procured from Sigma (Bangalore), Thermo Scientific (Mumbai) and Sigma- Aldrich (USA). The reagents and chemicals used for the PCR were PCR reaction buffer (10X), Taq DNA polymerase $(1 \mathrm{U} / \mu \mathrm{L})$, dNTP mix (2.0 mM), $\mathrm{MgCl}_{2}(25 \mathrm{mM})$, forward and reverse primer set $(100$ pmoles $/ \mu \mathrm{L})$ and sterilised milliQ water. The materials used for submarine agarose gel electrophoresis were Tris Boric acid EDTA (TBE), electrophoresis buffer $(1 \mathrm{X})$, agarose gel (1.5\%), gel loading buffer $(6 \mathrm{X})$, safe DNA staining solution and molecular weight marker (50 bp ladder).

Oligonucleotide primers targeting the uidA for $E$. coli were used in the study. The target gene that was detected by PCR and the primer sequences used (Alqahtani et al., 2015) in the study with some modifications are

Table 1. Primers used for the PCR identification of $E$. coli

\begin{tabular}{|c|l|c|c|}
\hline SI. No & Primers & Sequence & Size (bp) \\
\hline \multirow{2}{*}{1.} & uidA F & 5'TGGTAATTACCGACGAAAACGGC 3' & \multirow{2}{*}{162 bp } \\
\cline { 2 - 3 } & uidA R & 5'ACGCGTGGTTACAGTCTTGCG 3' & \\
\hline
\end{tabular}

Table 2. Components of PCR mixture for amplification of uidA gene

\begin{tabular}{|c|l|c|}
\hline SI. No & \multicolumn{1}{|c|}{ Name of reagents } & Quantity $(\boldsymbol{\mu L})$ \\
\hline 1. & Template DNA & 2.0 \\
\hline 2. & PCR buffer $(10 \mathrm{X})$ & 2.5 \\
\hline 3. & $\mathrm{MgCl}_{2}(25 \mathrm{mM})$ & 1.0 \\
\hline 4. & Taq polymerase $(1 \mathrm{U} / \mu \mathrm{L})$ & 0.5 \\
\hline 5. & dNTP mix $(2.0 \mathrm{mM})$ & 1.0 \\
\hline 6. & Forward primer $($ uidA) $(100 \mathrm{pmoles} / \mu \mathrm{L})$ & 1.0 \\
\hline 7. & Reverse primer $($ uidA $)(100 \mathrm{pmoles} / \mu \mathrm{L})$ & 1.0 \\
\hline 8. & Nuclease free water & 16.0 \\
\hline \multicolumn{2}{|c|}{ Total } & 25.0 \\
\hline
\end{tabular}


Table 3. Temperature and cyclic conditions for uidA gene

\begin{tabular}{|c|l|l|l|}
\hline SI. No & \multicolumn{1}{|c|}{ Steps } & Conditions & No. of cycles \\
\hline 1. & Initial denaturation & $94^{\circ} \mathrm{C}$ for $10 \mathrm{~min}$ & \\
\hline 2. & Denaturation & $94^{\circ} \mathrm{C}$ for $40 \mathrm{sec}$ & \multirow{2}{*}{35 cycles } \\
\cline { 1 - 3 } 3. & Annealing & $55^{\circ} \mathrm{C}$ for $60 \mathrm{sec}$ & \\
\hline 4. & Extension & $72^{\circ} \mathrm{C}$ for $50 \mathrm{sec}$ & \\
\hline 5. & Final extension & $72^{\circ} \mathrm{C}$ for $5 \mathrm{~min}$ & \\
\hline
\end{tabular}

Table 4. Occurrence of $E$. coli in broiler chicken by culture techniques

\begin{tabular}{|c|c|c|c|c|c|c|}
\hline \multirow{2}{*}{$\begin{array}{c}\text { SI. } \\
\text { No. }\end{array}$} & \multirow{2}{*}{ District } & \multirow{2}{*}{$\begin{array}{c}\text { Total } \\
\text { samples } \\
\text { analysed }\end{array}$} & \multicolumn{2}{|c|}{ Positive samples } & \multirow{2}{*}{ Chi-square } & \multirow{2}{*}{ p-value } \\
\hline & & & Number & Per cent & & \\
\hline 1 & Kollam & 200 & 153 & 76.5 & \multirow{3}{*}{$0.361^{\mathrm{ns}}$} & \multirow{3}{*}{0.548} \\
\hline 2 & Kottayam & 200 & 158 & 79.0 & & \\
\hline & Total & 400 & 311 & 77.8 & & \\
\hline
\end{tabular}

$\mathrm{p}<0.05$ - significant, ${ }^{\mathrm{ns}}$ - Non significant

Table 5. Occurrence of E. coli in broiler chicken by PCR

\begin{tabular}{|c|c|c|c|c|c|c|}
\hline \multirow{2}{*}{$\begin{array}{l}\text { SI. } \\
\text { No. }\end{array}$} & \multirow{2}{*}{ District } & \multirow{2}{*}{$\begin{array}{c}\text { Total } \\
\text { samples } \\
\text { analysed }\end{array}$} & \multicolumn{2}{|c|}{ Positive samples } & \multirow{2}{*}{ Chi-square } & \multirow{2}{*}{ p-value } \\
\hline & & & Number & Per cent & & \\
\hline 1 & Kollam & 200 & 113 & 56.5 & \multirow{3}{*}{$4.668^{s}$} & \multirow{3}{*}{0.031} \\
\hline 2 & Kottayam & 200 & 134 & 67.0 & & \\
\hline & Total & 400 & 247 & 61.8 & & \\
\hline
\end{tabular}

$p<0.05-$ significant, ${ }^{\text {s- significant }}$

shown in Table 1. The components of reaction mixture for one reaction are shown in Table 2. The annealing temperature used for the primers of uidA gene was $55^{\circ} \mathrm{C}$ as depicted in Table 3. The PCR products were stained with SYBR safe dye and detected by submarine gel electrophoresis.

\section{Results and discussion}

\section{Isolation and identification of E. coli}

In the present study, isolation and identification of $E$. coli was done from cloacal swabs of broiler chicken. Similar type of samples were used in various studies conducted by Zinnah et al. (2007) from Mymensingh and Ejeh et al. (2017) from Nigeria. During the study, the samples were collected in peptone water and further streaked on EMB agar for the selective isolation of $E$. coli. The colonies with characteristic metallic sheen with black centre were identified as $E$. coli. Biochemical tests were used for further characterisation of the organism. This was same as that of the study conducted by Samanta et al. (2014) from West Bengal, India, and Akond et al. (2009) from Bangladesh.

\section{Occurrence of E. coli in Broiler Chicken by Culture Techniques}

The occurrence of $E$. coli in cloacal swabs of broiler chicken from Kollam district was 76.5 per cent and that of Kottayam district was 79 per cent. Altogether 77.8 per cent overall occurrence from both districts were observed Statistical analysis using Pearson Chi-square test revealed that, there is no significant difference $(p>0.05)$ between the occurrence of $E$. coli in broiler chicken from Kollam and Kottayam (Table 4). A study conducted by Kwoji et al. (2019) from Maiduguri reported 77.05 per cent occurrence of $E$. coli from broiler chickens, which is in accordance with the present study. 
Eze et al. (2013) from Nigeria and Stella et al. (2016) from Brazil investigated the occurrence of $E$. coli in cloacal swabs from broiler chicken. The study reported 37 and 60 per cent $E$. coli occurrence, which was low when compared to the results of the present study. Also 100 per cent occurrence of E. coli in cloacal swabs of broiler chicken were recorded in a study by Wibisono et al. (2020) from Blitar, Indonesia.

Escherichia coli is a normal innocuous inhabitant of gastrointestinal tract of man and animals, hence the chance of occurrence is more. Even though they are the common inhabitant in gastrointestinal tract, some of them are pathogenic in nature and are responsible for causing various foodborne illness. Immunocompromised hosts and poultry are negatively affected with pathogenic $E$. coli. In humans $E$. coli responsible for various conditions like endocarditis, meningitis, urinary tract infection, septicemia, epidemic diarrhoea, whereas in case of poultry it causes omphalitis, cellulitis, yolk sac infection, swollen head syndrome, coligranuloma, and colibacillosis. Although most of them are non-pathogenic, they are used as indicators of faecal contamination (Akond et al., 2009). Unhygienic and poor management may contribute to the high occurrence of $E$. coli organisms in poultry.

\section{Confirmation of E. coli by PCR}

Molecular confirmation of $E$. coli in the current study was done by targeting uidA gene. Bej et al. (1991) from Connecticut used this gene as a suitable PCR target for $E$. coli. The study by Abdelrahman et al. (2008) also revealed that, PCR could be used as a routine diagnostic technique for rapid detection of $E$. coli using uidA gene primers.

In this study, PCR confirmed 56.5 and 67 per cent samples as positive for $E$. coli from Kollam and Kottayam districts, respectively. The occurrence of PCR confirmed $E$. coli isolate in broiler chicken from Kollam and Kottayam differ significantly $(p<0.05)$. Altogether, an occurrence of 61.8 per cent E. coli positive samples were detected from both districts by PCR (Table 5).
Hossain et al. (2008) and Nazir (2004) from Bangladesh reported 60 and 62.5 per cent occurrence of $E$. coli, which is in perfect tune with the present study. A low occurrence of 36.11 per cent noticed in cloacal swabs of broiler chicken by Andrews and Aswathy (2019) from Wayanad, Kerala. Compared to the present results, highest occurrence of 90.7 and 100 per cent were reported by Saidani et al. (2017) from Tunisia and Meguenni et al. (2019) from Central Algeria, respectively.

Escherichia coli is the most frequently seen pathogen associated with foodborne disease outbreaks, which is often identified by $\beta$-glucuronidase enzymatic activity or by detection of uidA gene by PCR. Since this house keeping gene found in almost all E. coli (Bej et al., 1991), it was considered as a suitable PCR target in this study. According to the report by Fratamico (2003), PCR based techniques was more sensitive than culture technique. This also revealed the importance of PCR in the present study.

\section{Conclusion}

From the study, it was concluded that an overall occurrence of 77.8 per cent samples were positive for $E$. coli by culture techniques. The samples which were subjected to conventional culture techniques were further analysed for PCR confirmation. The study revealed that, 61.8 per cent samples were confirmed for $E$. coli by PCR. Since $E$. coli is one among the common foodborne pathogens, there is a need for surveillance and control of this organism. A multifaceted One Health approach can combat foodborne diseases. This includes collaborative approach by various disciplines including human medicine, veterinary medicine, epidemiology, environmental specialist, public health institutes and epidemiological surveillance agencies. Upgradation and proper implementation of biosecurity measures are mandatory to control the spread of foodborne zoonotic pathogens.

\section{Acknowledgement}

The authors are thankful to the Kerala Veterinary and Animal Sciences University for providing the facilities needed for carrying out the research. 


\section{Conflicts of interest}

There were no conflicts of interest reported by the authors.

\section{References}

Abdelrahman, I.O., Elbagir, N.M., Osman, A.M.A., Sharfi, S.A., Saeed, A.M.A., Musa, H.A., Ashmaig, A.A. and Aradaib, I.E. 2008. PCR Detection of $E$. coli in Chicken Fecal Samples. Int. J. Mol. Med. Adv. Sci. 4: 82-85.

Akond, M.A., Alam, S., Hassan, S.M.R. and Shirin, M. 2009. Antibiotic resistance of Escherichia coli isolated from poultry and poultry environment of Bangladesh. Int. J. Food Safety. 11: 19-23.

Alqahtani, J.M., Asaad, A.M., Ahmed, E.M. and Qureshi, M.A. 2015. Drinking water quality and public health in Southwestern Saudi Arabia: The need for a national monitoring program. J. Family Community Med. 22: 19.

Andrews, H.P.and Aswathy, S.2019. Occurrence of Escherichia coli in Broilers and their Farm Settings. J. Foodborne Zoonotic Dis. 7: 1-4.

Bej, A.K., Dicesare, J.L., Haff, L. and Atlas, R.M. 1991. Detection of Escherichia coli and Shigella spp. in water by using the polymerase chain reaction and gene probes for uid. Appl. Environ. Microbiol. 57: 1013-1017.

Ejeh, F.E., Lawan, F.A., Abdulsalam, H., Mamman, P.H. and Kwanashie, C.N. 2017. Multiple antimicrobial resistance of Escherichia coli and Salmonella species isolated from broilers and local chickens retailed along the roadside in Zaria, Nigeria. Sokoto J. Vet. Sci. 15: 4553.

Eze, E., Nwakeze, E., Oji, A., Ejikeugwu, C. and Iroha, I. 2013. Microbiological investigation of Escherichia coli isolates from cloacal and feacal swabs of broiler chickens for extended-spectrum beta-lactamase (ESBL) enzymes. J.
Pharmacy Biological Sci. 7: 96-99.

Fratamico, P.M. 2003. Comparison of culture polymerase chain reaction (PCR), TaqMan Salmonella, and Transia Card Salmonella assays for detection of Salmonella spp. in naturallycontaminated ground chicken, ground turkey, and ground beef. Mol. Cell. Probes. 1: 215-221.

Hossain, M.T., Siddique M.P., Hossain, F.M.A., Zinnah, M.A., Hossain, M.M., Alam, M.K., Rahman, M.T., and Choudhury, K.A. 2008. Isolation, identification, toxin profile and antibiogram of $E$. coli isolated from broilers and layers in Mymensingh district of Bangladesh. Bangladesh $J$. Vet. Med. 6: 1-5.

Kwoji, I.D., Musa, J.A., Daniel, N., Mohzo, D.L., Bitrus, A.A., Ojo, A.A. and Ezema, K.U. 2019. Extended-spectrum betalactamase-producing Escherichia coli in chickens from small-scale (backyard) poultry farms in Maiduguri, Nigeria. Int. J. One HIth. 5: 26-30.

Lee, S. H., Jung, B. Y., Rayamahji, N., Lee, H. S., Jeon, W.J., Choi, K. S., Kweon, C. H. and Yoo, H. S. 2009. A multiplex real-time PCR for differential detection and quantification of Salmonella spp., Salmonella enterica serovar Typhimurium and Enteritidis in meats. $J$. Vet. Sci. 10: 43-51.

Meguenni, N., Chanteloup, N., Tourtereau, A., Ahmed, C.A., Bounar-Kechih, S. and Schouler, C. 2019. Virulence and antibiotic resistance profile of avian Escherichia coli strains isolated from colibacillosis lesions in central of Algeria. Vet. WId. 12: 1840.

Nazir, K.H.M.N.H. 2004. Molecular base of diversified E. coli potentiating antibiotic resistant pattern and compromising epidemiology. MS Thesis, Department of Microbiology and Hygiene, BAU, Mymensingh-2202.

Saidani, M., Tabib, I., Chaouechi, A., Zouaoui, 
S., Soudani, A., Haenni, M., Daaloul, M., Ben, F., Chehida, A., Chakroun, C. and Madec, J. 2017. Surveillance of antimicrobial resistance in Escherichia coli strains isolated from cattle and broiler chickens in Tunisia. J. New Sci. 25: 1-6.

Samanta, I., Joardar, S.N., Das, P.K., Sar, T.K., Bandyopadhyay, S., Dutta, T.K. and Sarkar, U. 2014. Prevalence and antibiotic resistance profiles of Salmonella serotypes isolated from backyard poultry flocks in West Bengal, India. J. Appl. Poult. Res. 23: 536-545.

Stella, A.E., Oliveira, M.C.D., Fontana, V.L.D.D.S., Maluta, R.P., Borges, C.A. and Ávila, F.A.D. 2016. Characterisation and antimicrobial resistance patterns of Escherichia coli isolated from faeces of healthy broiler chickens. Arq. Inst. Biol. 83: $1-5$.

WHO (World Health Organisation). 2015. WHO estimates of the global burden of foodborne diseases: foodborne disease burden epidemiology reference group 2007-2015. World Health Organisation, Geneva, 265p.
Wibisono, F.J., Sumiarto, B., Untari, T., Effendi, M.H., Permatasari, D.A. and Witaningrum, A.M. 2020. CTX Gene of Extended Spectrum Beta-Lactamase (ESBL) Producing Escherichia coli on Broilers in Blitar, Indonesia. Sys. Rev. Pharm. 2020. 11: 396-403.

Yulistiani, R. and Praseptiangga, D. 2019. Occurrences of Salmonella spp. and Escherichia coli in chicken meat, intestinal contents and rinse water at slaughtering place from traditionalmarket in Surabaya, Indonesia. International Conference on Food Science and Engineering, 25-26 September 2018, Central Java, Indonesia. 7p.

Zinnah, M.A., Bari, M.R., Islam, M.T., Hossain, M.T., Rahman, M.T., Haque, M.H., Babu, S.A.M., Ruma, R.P. and Islam, M.A. 2007. Characterisation of Escherichia coli isolated from samples of different biological and environmental sources. Bangladesh J. Vet. Med. 1: 2532. 